\title{
Engineering Course Model on STEM Education for Middle School Curriculum Setting in Indonesia
}

\author{
Setiya Utari ${ }^{1}$, Eka Cahya Prima ${ }^{2}$, Irma Rahma Suwarma ${ }^{3}$, Andi Suhandi ${ }^{4}$ \\ \{ setiyautari@upi.edu' ${ }^{1}$, ekacahyaprima@upi.edu ${ }^{2}$ \} \\ Department of Physics Education, Faculty of Mathematics and Science Education, Universitas \\ Pendidikan Indonesia, Bandung, Indonesia ${ }^{1,3,4}$ \\ Department of Science Education, Faculty of Mathematics and Science Education, Universitas \\ Pendidikan Indonesia, Bandung, Indonesia ${ }^{2}$
}

\begin{abstract}
The science, technology, engineering, and mathematics education (STEM) provides a high opportunity in exercising this skill to students. Based on our investigation, the difficulties might be handled by applying the engineering course model. The class can be conducted separately as an independent subject such as the basic technical education, which is provided as a particular subject in a private school, or extracurricular activity of students' science forum for whom interested to this subject. To facilitate a well-scientific activity, the model of engineering curricula is needed especially to train the 21 th-century skill. Thus, this work has reported the survey of STEM education activities implemented at some middle schools, the interviews with some teachers who are responsible for the science subject, and the analysis of science subject contents in Indonesian curricula 2013 for the middle school level.
\end{abstract}

Keywords: The 21th-century skill, STEM education, Curriculum, Engineering course

\section{Introduction}

The human resources having extensive abilities are needed by the developing countries and the developed countries at present. These abilities are expected to handle worldcomprehensive problems such as the energy crisis, global warming, the massive human population growth, health, and natural disasters. Moreover, the problems could be solved by applying the multidisciplinary aspects including critical thinking skills, communication skills, collaboration skills, and the use of recent technologies. All these abilities are commonly included in the $21^{\text {th }}$-century skill. The skills consist of (a) the critical thinking focusing on problem investigation, (b) examining the result of solved problem, (c) the creative thinking to seek the alternative solutions, (d) developing the effective-efficient engineering process based on solving the problem, (e) the communication skills on searching for the information and elucidating the result finding using the multi-representative method, (f) the team collaboration skills on finding the efficiently strategic ways to solve the problems, (g) the technology literacy on understanding science, constructing the engineering process, and resolving the problems [1].

The more the growth of science and technology, the more the complex problems to be solved by humans utilizing a higher-level skill. On the other hand, the massive global market improves social competitiveness to create a high-quality product as a new challenging 
problem. Therefore, some countries decide to develop the educational curriculum facilitating $21^{\text {th }}$-century skills [2]. Although the skill could be trained using a specific science discipline, it could be justified that the problem solving needs multiple science disciplines. A student requires the broadening experience to gain his knowledge, so he is unable to work together with other students having other science disciplines to answer their problem [3]. Thus, the innovative strategy to exercise the $21^{\text {th }}$-century skill will be proposed to handle their complex difficulties.

STEM education offers the students the opportunity to work the $21^{\text {th }}$-century skill out [4]. The education introduces the utilization of multidiscipline science to analyze the problems, to explore alternative solutions, to apply the engineering process on the technical design, to work scientifically, and to communicate the result considering the strengths and the weaknesses [5]. To convey the students' perception of multidiscipline science. STEM education also provides the crosscutting concept to elaborate the problem and solution consisting of seven elements such as the pattern, the cause, and effect, the scale, the quantity and proportion, the system and system model, the energy and matter, the structure and function, the stability and instability [6].

The research in STEM education has been being extended. The model combines two or three science disciplines, as illustrated in Figure 1. This pattern describes the utilization of a combined two or three disciplines science as a basic knowledge to create a new product or to understanding an existing technology [7]. The design of the engineering course model could employ a combined science and technology that might be adapted to develop the engineering courses such as the basic technology education (BTE) course, the students' science forum (KIR) in Indonesian middle school curriculum.

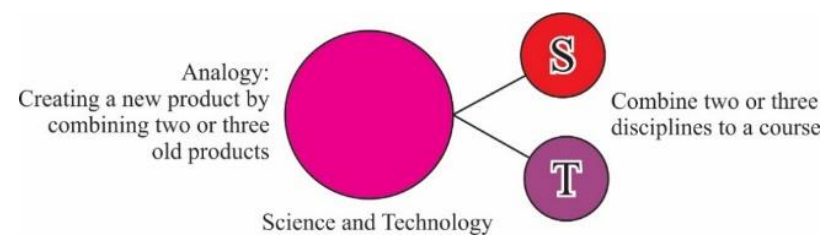

Fig. 1. STEM education model illustration.

\section{Research Method}

This descriptive research aims to construct the engineering course model at the middle schools having the basic technology education course as a formal program or the students' science forum as an extracurricular program. The research involves three private schools and three public schools. These private schools possess the basic technology education course and the research-based learning class, while the public schools have the students' science forum. The participants are interviewed in terms of the program curricula of the courses, the product characteristics resulted from the learning process, and the teamwork performance of the different students' groups in the students' science forum. The mathematics and science curricula including the popular science contents in these middle schools are also analyzed to construct the course content model curricula. 


\section{Result and Discussion}

According to the interview, it can be described the curricula implemented at the private school as well as the public school as follows:

\subsection{The curricula of the basic technology education course}

This course has possessed a well-organized curriculum, the learning module, and the primary laboratory. The course is also related to making a student's project following the engineering process. The work was using a pattern called "thinking, drawing, making, and testing". The projects developed in this course are highly dominated by the physics content based on the physics curriculum in the same grade, so the students are expected to be able to actively learn this course. However, the assessment doesn't evaluate the learning outcome referred to as $21^{\text {th }}$-century skills. Consequently, we recommend that a well-organized assessment needs to be developed. This course is introduced as a pilot study involving the 50 schools to improve the educational technology in Indonesia, but the program is no longer continued and recently categorized as an optional course. Figure $\mathbf{2}$ shows the curriculum model on the developed engineering course implemented in the basic technology education course as well as in the students' science forum.

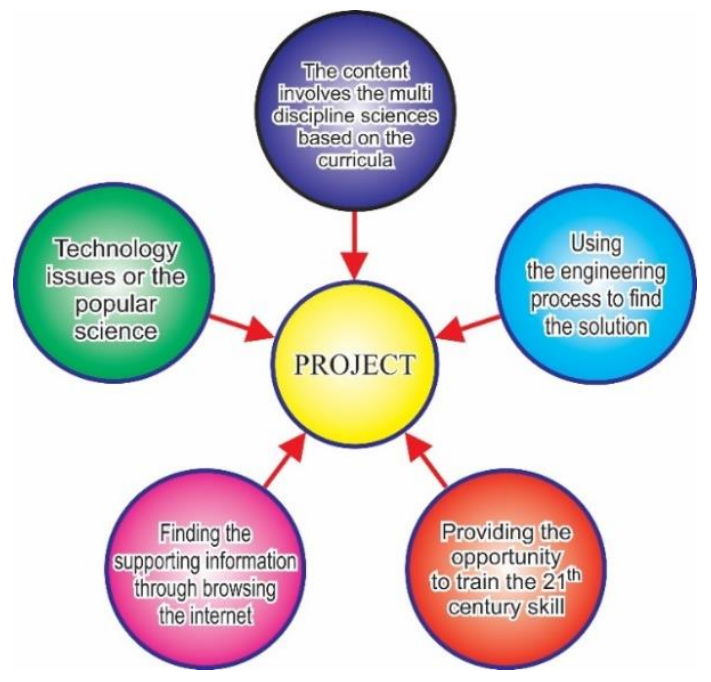

Fig. 2. Curriculum model on the developed engineering course.

\subsection{The curricula of the research-based learning class or the students' science forum}

This class is categorized as an extracurricular program. Not all of the students are involved in this activity so that the students having excellent science interest may join this program. A school classifies the students' science forum based on the student's grade, while the other schools group the forum in terms of their activities on certain science topics. It can also be found that some schools don't have the standard curricula to arrange the science 
investigation activities. Table 1 tabulates the students' project activities including their reasons implemented by some private and public schools based on the interview.

Table 1. The interview result of the students' project activities.

\begin{tabular}{|c|c|c|}
\hline Schools & Students' project activities & Reasons \\
\hline $\begin{array}{l}1^{\text {st }} \text { Private } \\
\text { school }\end{array}$ & $\begin{array}{l}\text { The projects have been } \\
\text { constructed regarding the science } \\
\text { concept comprehension following } \\
\text { the curriculum }\end{array}$ & $\begin{array}{l}\text { The school needs to construct an } \\
\text { exceptional program and it can attract } \\
\text { outstanding prospective students to be well- } \\
\text { trained in Science Olympiad. }\end{array}$ \\
\hline $\begin{array}{l}2^{\text {nd }} \text { Private } \\
\text { school }\end{array}$ & $\begin{array}{l}\text { The projects were constructed } \\
\text { based on popular science } \\
\text { information, and these are not } \\
\text { always related to the curriculum } \\
\text { provided by the school. }\end{array}$ & $\begin{array}{l}\text { The activity was initiated by science } \\
\text { teachers to gain the students' knowledge of } \\
\text { the current science issues in the world. }\end{array}$ \\
\hline $1^{\text {st }}$ Public school & $\begin{array}{l}\text { The experiments have been } \\
\text { constructed based on the } \\
\text { curriculum. }\end{array}$ & $\begin{array}{l}\text { The school has insufficient tools and they } \\
\text { attempt to facilitate students to be interested } \\
\text { in science. }\end{array}$ \\
\hline $\begin{array}{l}2^{\text {nd }} \text { Public } \\
\text { school }\end{array}$ & $\begin{array}{l}\text { Some projects had been } \\
\text { developed certain years ago } \\
\text { before other projects were created } \\
\text { based on the internet. }\end{array}$ & $\begin{array}{l}\text { The students' science forum was guided } \\
\text { intensively, so they have some well- } \\
\text { developed projects }\end{array}$ \\
\hline $3^{\text {rd }}$ Public school & $\begin{array}{l}\text { The students propose the projects } \\
\text { duplicated from the internet. }\end{array}$ & $\begin{array}{l}\text { The students' science forum was no longer } \\
\text { established. Consequently, the curriculum } \\
\text { needs to be further developed. }\end{array}$ \\
\hline
\end{tabular}

The Indonesian science curriculum hasn't also provided a well-integrated science yet, so the science contents are separated as physics, chemistry, and biology. On the other hand, this curriculum expects some science topics of force and motion conducted in physics courses to be applied in biology applications such as the understanding of the human muscular system. Unfortunately, this subject has not conducted comprehensively. Therefore, the STEM education might be suggested as an integrated approach to understanding the science topic referred to as the students' science project as shown in Figure 3.

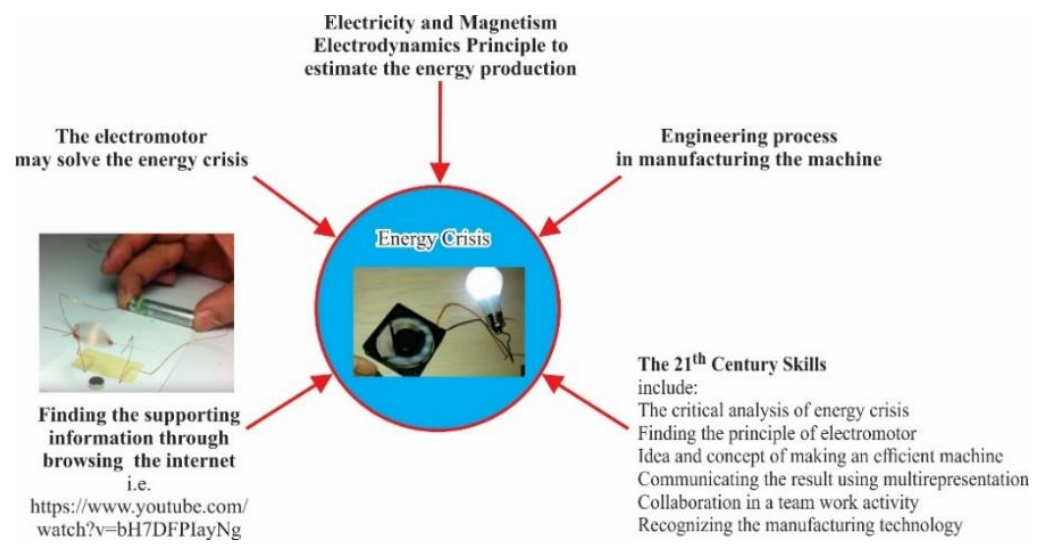

Fig. 3. Model of a project made in the engineering course. 


\section{Conclusion}

The engineering course curriculum model on the students' science forum activities, the basic technology education course, and the research-based learning class has been developed to train the engineering process as well as the $21^{\text {st }}$-century skills. The technology issues are given to the students close to the curriculum contents of mathematics and science in the same grade. Students need supporting knowledge in solving their problems during making a project by browsing the internet. Considering this model is constructed based on the prior direct experience and the curriculum analysis, the research implied that the learning instrument including its implementation should be improved to be well organized as a validated reference for exercising the $21^{\text {st }}$-century skills on the engineering course.

\section{References}

[1] Greenhill, V.: 21st Century Knowledge and Skills in Educator Preparation. Partnership for 21st century skills. New York: Pearson (2010).

[2] National Research Council.: A framework for K-12 science education: Practices, crosscutting concepts, and core ideas. Washington D.C.: National Academies Press (2012).

[3] Zemelman, S., Daniels, H., \& Hyde, A.: Best practice: Today's standards for teaching and learning in America's schools. Education Review//Reseñas Educativas. Portsmouth: Heinemann Educational Publishers (2005).

[4] Beers, S. Z.: $21^{\text {st }}$-century skills: Preparing students for THEIR future. New York: McGraw Hill Education (2011)

[5] Yasin, A. I., Prima, E. C., \& Sholihin, H.: Learning Electricity using Arduino-Android based Game to Improve STEM Literacy. Journal of Science Learning, 1(3), pp. 77-94 (2018).

[6] Bybee, R. W.: NGSS and the next generation of science teachers. Journal of science teacher education, 25(2), pp. 211-221 (2014).

[7] Bybee, R. W.: The case for STEM education: Challenges and opportunities. Arlington: NSTA press (2013) 